\title{
The Life Course of a Standard-Bearer: A Nonroyal Elite Burial at the Maya Archaeological Site of El Palmar, Mexico
}

\author{
Jessica I. Cerezo-Román (1D) and Kenichiro Tsukamoto
}

\begin{abstract}
Inspired by life course and osteobiography approaches, this article explores the life and death of an individual associated with the lakam title ("banner" in Colonial Yukatek Maya; thus, a "standard-bearer"), a nonroyal elite of Late Classic period Maya society (AD 600-850). Although these elites are depicted on polychrome vessels and carved monuments, little is known about their life experiences and mortuary practices. The present analysis centers on an individual found at Structure GZ1, a temple with a hieroglyphic stairway, at the Maya archaeological site of El Palmar, Mexico. Using osteological, archaeological, and epigraphic data as different lines of evidence, we examine the relationship of the individual to his affiliated group. At the time of interment, there were a wide array of social, cultural, and political events both shaping and reshaping the body and identities of the individual during a period of political turbulence.
\end{abstract}

Keywords: life course, bioarchaeology, Classic Maya society, lakam, El Palmar

Inspirado por los enfoques del curso de la vida y osteobiografía, este artículo explora la vida y muerte de un individuo asociado con el título lakam ("bandera" en Yukateka maya colonial, por lo tanto, "abanderado"), o una élite no-real de la sociedad maya del período Clásico tardío (600-850 dC). Aunque estas élites se representan en las vasijas policromadas y monumentos tallados, casi no se saben sobre sus experiencias de vida y práctica mortuoria. El presente análisis se centra en un individuo encontrado en la Estructura GZ1, un templo con una escalinata jeroglífica, en el sitio arqueológico maya de El Palmar, México. A través de los datos osteológicos, arqueológicos y epigráficos como diferentes líneas de evidencia, examinamos la relación del individuo con su grupo afiliado. En el momento del entierro, hubo una amplia gama de eventos sociales, culturales y políticos que dieron forma y remodelaron el cuerpo y las identidades del individuo durante un período de turbulencia política.

Palabres claves: curso de vida, bioarqueología, período Clásico sociedad Maya, lakam, El Palmar

$\mathrm{T}$ The application of life course and osteobiography approaches to the remains of individuals in the archaeological record allows researchers, in more fluid and holistic ways, to begin reconstructing who those individuals were as people, some of their life experiences, and how they were treated and remembered by their family at death. Inspired by these approaches, this article applies a multifaceted methodology that draws on osteological, archaeological, and epigraphic data to gain a better understanding of the life and death of an individual buried at the Maya site of El Palmar, Mexico. Epigraphic studies suggest that this individual had the title of lakam ("banner" in Colonial Yukatek Maya; thus, a "standard-bearer"), an important political position during the Late Classic period (AD 600-800).

In ancient Mesoamerica, standard-bearers played crucial political and economic roles (Braswell 2003; Houston and Stuart 2001; Lacadena 2008; Palka 2014; Rice 2007; Tsukamoto and Esparza Olguín 2004). Nevertheless, their life history and physical characteristics have

Jessica I. Cerezo-Román ( jessica.cerezoroman@ ou.edu; corresponding author) — Department of Anthropology, University of Oklahoma, 455 W. Lindsey St., Dale Hall Tower Room 509, Norman, OK 73019, USA

Kenichiro Tsukamoto — Department of Anthropology, University of California, Riverside, 900 University Ave., 1334 Watkins Hall, Riverside, CA 92521, USA (kenichiro.tsukamoto@ucr.edu)

Latin American Antiquity 32(2), 2021, pp. 274-291

Copyright (C) The Author(s), 2021. Published by Cambridge University Press on behalf of the Society for American Archaeology. This is an Open Access article, distributed under the terms of the Creative Commons Attribution licence (http://creativecommons.org/licenses/by/4.0/), which permits unrestricted re-use, distribution, and reproduction in any medium, provided the original work is properly cited. 
remained unknown, mainly because few burials of known standard-bearers have been found in the archaeological record. An exceptional case is El Palmar where we find long inscriptions that depict genealogical ties between standardbearers and its north plazuela group (Tsukamoto et al. 2015). This article demonstrates how a multifaceted approach can, through several lines of evidence, provide a holistic view of changing identities over time at an individual level.

\section{Life Course and Osteobiography}

Life course analysis combines concepts and methods from disciplines such as anthropology, sociology, psychology, and history (Inglis and Halcrow 2018). This approach has gained popularity in bioarchaeological studies because it more holistically connects individuals with the historical and socioeconomic contexts in which they lived (Agarwal 2012; Elder et al. 2004; Gilchrist 2012; Glencross 2011; Knudson and Stojanowski 2008). A critical aim of the approach is to understand the human life experience as a continuum, rather than compartmentalizing the analysis into datasets that correspond to successive segmented stages of life, such as infancy, childhood, adolescence, or old age (Inglis and Halcrow 2018).

Contextualization of gender and aging has been crucial in the development of the life course approach within archaeology and bioarchaeology. For example, researchers have examined the differences between physiological, chronological, and cultural ages within a group and the relationship between biological sex, as well as the cultural construction of gender (e.g., Agarwal 2012; Beauchesne and Agarwal 2018; Geller 2009, 2018; Gilchrist 1999; Glencross 2011; Hollimon 2017). Others have studied disability, disease, and social inequalities (Byrnes and Muller 2017; Hawkey 1998; Roberts 1999; Tilley and Oxenham 2011).

The body has also been a central focus of investigation in an attempt to bridge theoretical and methodological divisions between the study of human remains and socially informed archaeological interpretations of the past (Hollimon 2017). Sofaer (2006) emphasizes that the body is socially constructed and should be conceptualized as the union between the biological and material bodies. Archaeologists and bioarchaeologists have used embodiment theory to understand social constructions of the body, how individuals used their bodies, and how the body was perceived by past populations (Fisher and Loren 2003; Joyce 2001, 2005; Meskell 1999; Meskell and Joyce 2003; Perry and Joyce 2001). Embodiment describes how the physical body is shaped and how habits and practices are inscribed on the skeleton over the course of life through complex interactions between an individual's biology and the social context (Hollimon 2017; Joyce 2001, 2002). Several researchers have juxtaposed identity and embodiment using a variety of data from the archaeological record (Fisher and Loren 2003; Joyce 2005; McClelland and Cerezo-Román 2016; Meskell 1999; Meskell and Joyce 2003; Perry and Joyce 2001). Those using a life course approach at the population level have been successful in exploring the biological body and the social body (e.g., Agarwal 2012; Agarwal and Wesp 2017; Beauchesne and Agarwal 2018; Gilchrist 2000; Gowland 2006; Sofaer 2006). Nevertheless, the application of this approach at the individual level is challenging. Through applying osteobiographic principles in conjunction with embodiment and the life course approach, we attempt to overcome some of the difficulty in reconstructing individual life histories.

Inspired by Krogman's identification methods of human remains (Buikstra 2006; Krogman 1935), Frank and Julie Saul (Saul 1972; Saul and Saul 1989) introduced the term "osteobiography." This approach primarily stresses methodology and involves collecting data about demography or functional adaptations and pathologies from individual skeletons. The goal is to identify the individual biological profile in order to address questions ranging from health, diet, and occupation to the status of women in the past (Buikstra 2006; Buikstra and Scott 2009; Geller 2012; Watson and Stoll 2013). Following Saul (1972; see also Saul and Saul 1989) and Hawkey (1998), Stodder and Palkovich (2012) emphasize the osteobiographical approach as a useful methodological and theoretical framework for understanding the life history of individuals.

Subsequently, these ideas were expanded and elaborated on by considering the connection of 
the individual to the broader group, moving away from a strictly descriptive and functional approach. For example, several researchers (e.g., Grosman et al. 2008; Voss 2005; Whelan 1991) used the osteobiographical method to analyze specific individuals within a group. Robb (2002) proposed that osteobiography should be treated as a cultural narrative or story of a person that stresses the past life events of individuals and the postdepositional processes affecting their remains. Geller (2012) and Geller and Suri (2014), in contrast, emphasize life and death histories to examine the identities of individuals. Geller developed the concept of "death history" to describe the community's ongoing engagement with decedents' bodies and to better understand how individuals experience the world during life and death (Geller and Suri 2014). Whereas some researchers include death histories in their osteobiographical analyses (Mayes and Barber 2008), others focus only on individual biological and life experiences (Alfaro Castro et al. 2017; Lessa and Guidon 2002).

Inspired by the life course and osteobiographical approaches, this article analyzes an individual recovered from Burial 1 at El Palmar to assess who he was, some of his personal life experiences, and how he was treated and remembered at death by family members, mourners, and the broader community. We reconstruct the life history and osteobiography of this individual by combining data from the skeleton and his treatment at death with the archaeological and epigraphic data. Then, we discuss some issues we confronted in the research while attempting to reconstruct the life course of an individual as a continuum.

\section{El Palmar}

El Palmar is located at the eastern edge of the Central Karstic Uplands of the Yucatan Peninsula (Figure 1). Surrounding El Palmar are other large sites such as Tikal and Calakmul, the latter of which became the capital of the Snake Dynasty after AD 635 (Helmke and Awe 2016; Martin and Velásquez García 2016). El Palmar was occupied from the Late Preclassic to the Terminal Classic period (ca. $300 \mathrm{BC}-$ AD 850), with an urban transformation occurring during the Middle Classic (AD 400-600;

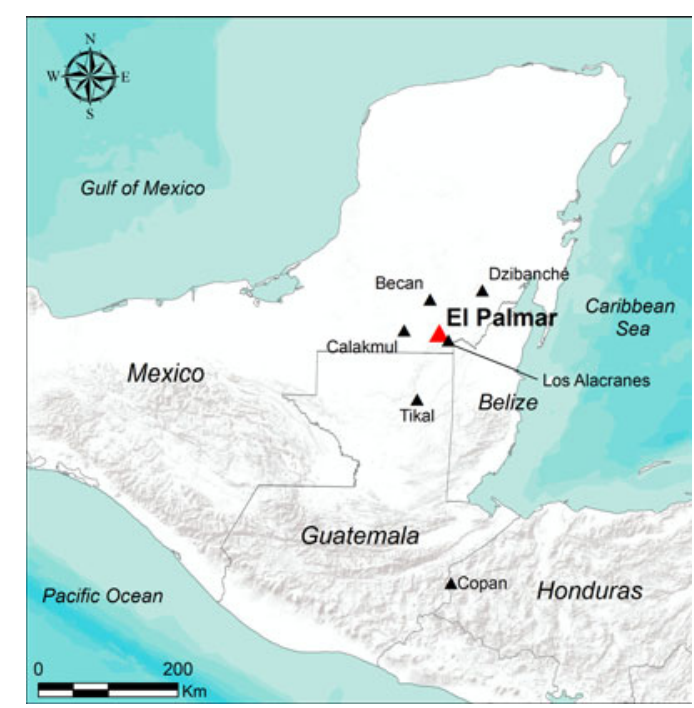

Figure 1. Map of Yucatan Peninsula showing the location of EI Palmar and other archaeological sites.

Tsukamoto 2014). Epigraphic studies revealed El Palmar's dynastic history from AD 554 to 820 , including political interactions with Calakmul (Esparza Olguín and Tsukamoto 2011).

During the 2009 field season, Tsukamoto documented the Guzmán Group, an outlying plazuela (a small plaza compound) located 1.3 $\mathrm{km}$ north of the Main Group. It comprised a small plaza surrounded by a temple (Structure GZ1) at its east end and six rectangular structures on the other sides (Figure 2). This particular spatial configuration is a typical layout known as Plaza Plan 2 in the Maya Lowlands (Becker 1991; Chase and Chase 2004). The eastern temples usually have a burial, and researchers have interpreted the individuals inside the burials as ancestors of the social groups who occupied these plazas (McAnany 1995). Extensive excavations revealed that the Guzmán Group began with scattered modest houses with chultunob by cal AD 321; it was transformed into a plazuela group by cal AD 682, serving as a location for administrative, ceremonial, and domestic activities (Tsukamoto et al. 2020). The excavations at Temple GZ1 exposed a hieroglyphic stairway that was built in AD 726 (Figure 3).

The inscriptions depict a standard-bearer who played the role of ambassador in negotiating political alliances between El Palmar, Copán, and 


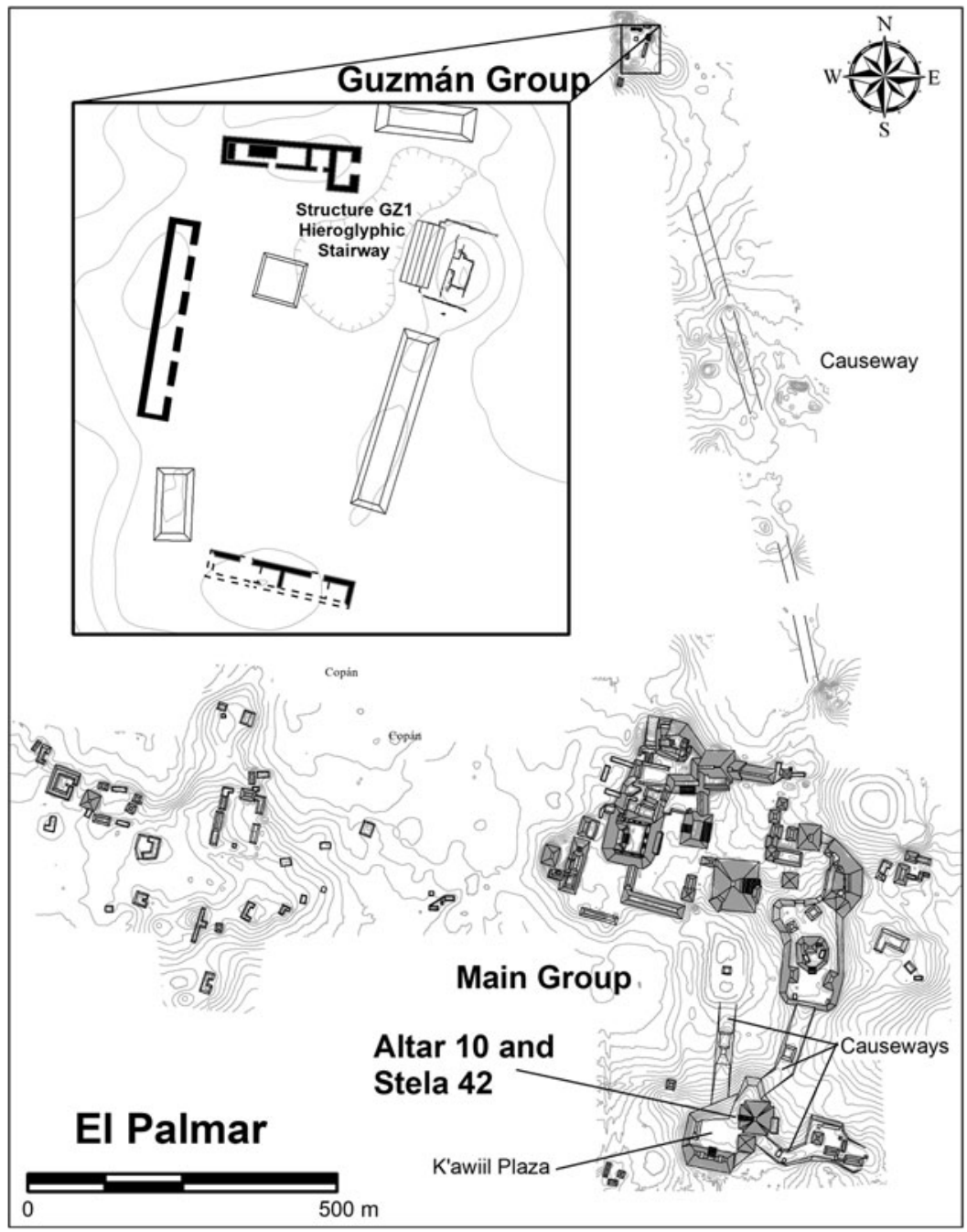

Figure 2. Map of the Main Group and the Guzmán Group at El Palmar.

Calakmul (Tsukamoto and Esparza Olguín 2015). In prehispanic Mesoamerica, standard-bearers were frequently depicted in procession, tributary, and ceremonial scenes on carved monuments, murals, and polychrome vessels and in graffiti (e.g., Kerr 1998:K680). Different lines of evidence including iconographic images suggest that they played important roles in constituting Mesoamerican polities. Among some of the earliest known examples are an Olmec carving on Monument 13 at La Venta, which shows a walking nobleman called the "Ambassador" (Rice 2007:96-97) or the "Walker" (Palka 2014:125). In this carving, a footprint or travel/arrival glyph appears alongside a person carrying a banner and arriving on foot to the site to participate in a ritual (Palka 2014:125). Historical accounts of lolmay or lolmet, the K'iche' name for ambassador, describe the importance of these type of nonroyal elites who served as intermediaries in negotiating political alliances between rulers (Braswell 2003).

Temple GZ1's text documents an individual, Ajpach' Waal, who was a descendant of standard-bearers (for more detailed information, see Tsukamoto and Esparza Olguín 2015). It commemorates his journey to the kingdom of Copán located $350 \mathrm{~km}$ to the south of El Palmar. On June 25, AD 726, he was allowed to meet 


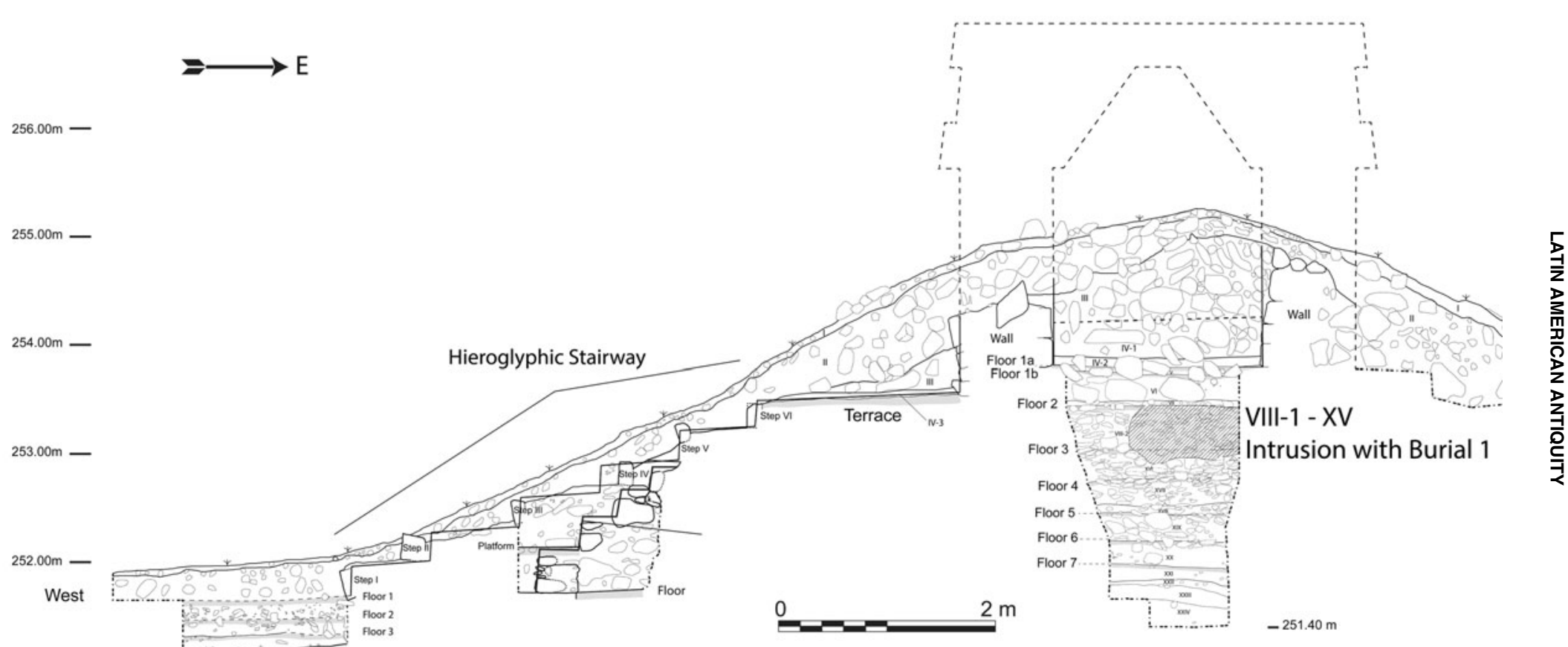

Figure 3. Excavated section of Structure GZ1 with the location of Burial 1. 
Waxaklajuun Ubaah K'awiil, Copán's thirteenth ruler. This event occurred most likely under the auspices of Calakmul (i.e., the Snake Dynasty), because one of its kings, Yuknoom Took' K'awiil, also appears in the texts. Three months later on September 13, AD 726 (or 9.14.15.0.0), Ajpach' Waal built the stairway, claiming his ownership of the temple and presumably of the entire Guzmán Group by listing his genealogical tie to lakam ancestors from his father, Ajlu...Chih, to his great-grandfather. The word lakam means banner in Colonial Yukatek Maya, and therefore people who hold the lakam title are considered standard-bearers. Some painted vessels depict lakam elites (or laka$m o b$ ) in tributary and processional scenes (Houston and Stuart 2001; Lacadena 2008; Stuart 2010). The genealogical list on the inscriptions probably indicates that the standard-bearers lived in the Guzmán Group for generations, which was common practice in ancient Maya society (McAnany 1995). In addition to the historical event and the genealogical list of standard-bearers, the center of the second step shows iconographic images of a large ball flanked by two ballplayers. The stairway was almost intact, meaning that it was most likely found in situ with minimum pre- and postabandonment alterations.

Stratigraphic excavation at a temple in its north architectural group uncovered a burial (Burial 1) containing an individual with two polychrome vessels as offerings (Tsukamoto et al. 2015). The individual is either Ajpach' Waal, who owned both the hieroglyphic stairway attached to the temple and presumably the entire Guzmán Group, or his father Ajlu...Chih, who also appears to have been a standard-bearer. This exceptional finding helps us piece together the life history of Classic period Maya standard-bearers.

\section{Burial 1 Analysis Results}

The primary inhumation burial (Burial 1) was found in a cist located underneath the floor of the upper shrine. The cist, which measures $2 \mathrm{~m}$ long, intrusively cuts into the fill of the previous plaster floors and was formed by seven stone slabs aligned from north to south. The individual lay extended with the head positioned toward the north. The bones were in relative anatomical position, and the degree of articulation suggests that the body decomposed in situ (Figure 4). The cist created a space that allowed minor movement of the skeletal elements as the body decomposed (Duday 2009). There is no archaeological evidence that the grave was ever reopened. The bones received minor biodisturbances from small animals such as rodents, soil, and plant roots.

Two polychrome vessels were placed at the north end of the cist as a mortuary offering. Although Tsukamoto mentioned these vessels elsewhere (Tsukamoto et al. 2015:207-208), it is worth describing their iconographic representations here because of their relation to the individual. The first vessel is a tripod bowl that depicts a bird on two sides with black feathers, a cormorant-like beak, and heron-like eyes that may represent an aquatic bird (Figure 5a; Schele and Miller 1986:55). The second one is a cylinder vase that represents two mythological scenes of the fire ritual (Figure 5b). In each scene an individual with a luxurious headdress sits on a decorated bench. Flames or smoke issues from the hands of the main individual, and a servant stands in front of (and in one case also behind) the individual; three bands of pseudo-glyphs are drawn on the upper register and in between the scenes. Two radiocarbon dates, in concordance with stratigraphic relations and ceramic types, suggest that the burial was interred around AD 726 when the stairway was constructed (Table 1; Tsukamoto et al. 2015).

Preservation of the skeletal remains allowed us to assess the sex of the individual, the age at death, some pathological conditions, and cultural modifications. Cranial, appendicular, axial, and extremity skeletal elements were identified and documented using osteological recording protocols proposed by Buikstra and Ubelaker (1994) and the Arizona State Museum (2018). Burial 1 was male and between 35 and 50 years old when he died (see Supplemental Text 1 for the details of our osteological analysis).

Oral pathologies include dental calculus, hypercementosis on the maxillary right first incisor, an abscess possibly associated with the mandibular right first premolar, and extensive antemortem tooth loss on the left side of the mandible with considerable alveolar reabsorption 


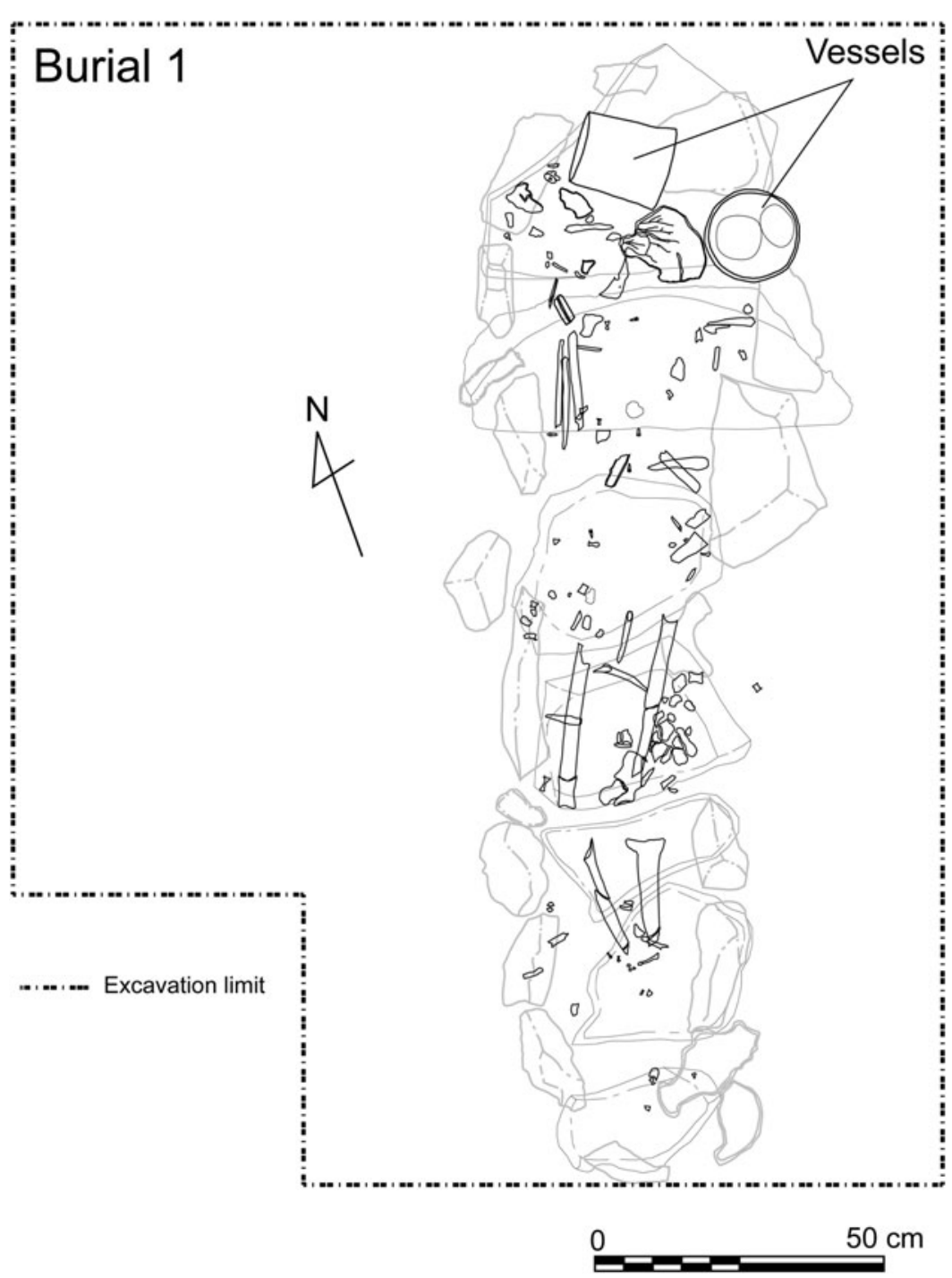

Figure 4. Burial 1.

(Figure 6). The teeth featured inlays from the right to left maxillary canine, classified as type E1 with dental alterations of the enamel (Romero Molina 1970; Tiesler et al. 2017; Williams and White 2006). Tabular cranial modification was observed on the occipital bone; because the frontal area was not completely preserved, it is not certain whether cranial modification was present on the forehead.

Additionally, the individual exhibited microporosity on the ectocranial surface in the left and right parietal, which is related to mild porotic hyperostosis (Supplemental Text 1). We also found a minor healed periosteal reaction on the radii, as well as a healed fracture on the distal midshaft of the right tibia (Figure 7a). Light to moderate degenerative joint disease was recorded on the carpal phalanges of one hand (side unknown), right ulna, left femur, and left patella, as well as on the proximal and distal tarsal phalanges (Figure 7b and 7c).

\section{Reconstructing the Life Course of the Individual in Burial 1}

A multifaceted approach allowed us to reconstruct aspects of the individual's life and how he was treated and remembered by the mourners 

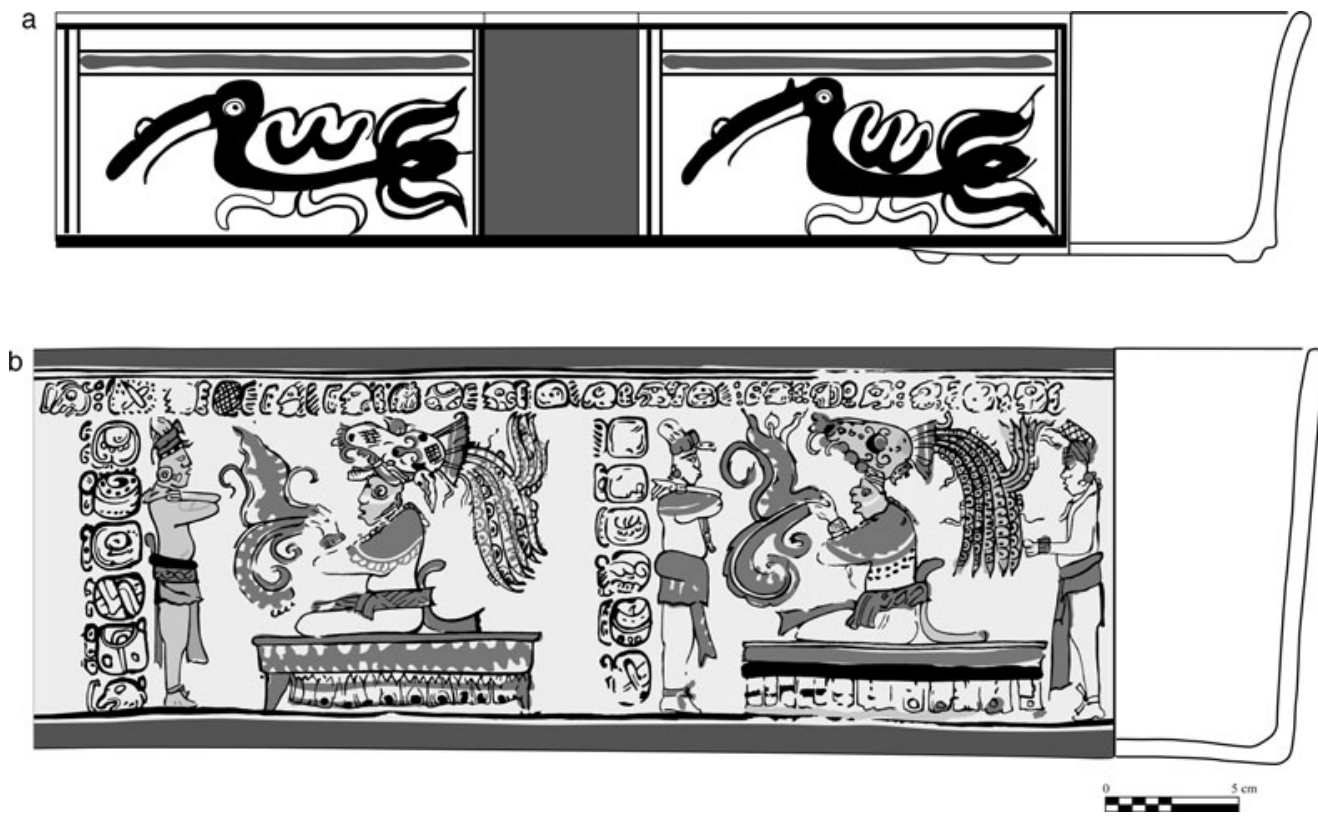

Figure 5. Rollout drawings of polychrome vessels recovered from Burial 1: (a) Zacatel Cream Polychrome tripod bowl (drawing by Kenichiro Tsukamoto); (b) Saxche Orange Polychrome cylinder vase (drawing by Daniel Salazar Lama and Kenichiro Tsukamoto).

and community in death. Simultaneously, we recognize that there exist limitations on the amount of information that the analysis of the human remains, archaeological context, and epigraphic evidence can provide, especially when studying a single individual and trying to elucidate his entire life course. Nevertheless, it is possible to infer some of the life history of this individual from early infancy to death.

The individual in Burial 1 at El Palmar allows us to broaden our understanding of nonroyal elites. He had mild porotic hyperostosis, which is a nonspecific health indicator often associated with childhood disease (Plumer 2017). Specifically, it articulates with megaloblastic and hemolytic anemias, as well as scurvy (Ortner and Ericksen 1997; Ortner et al. 2001; Walker et al. 2009; Zuckerman et al. 2014). In the Americas, Walker and colleagues (2009) suggest that this condition is commonly due to megaloblastic anemia caused by dietary deficiencies and malabsorption of vitamins B12 or folic acid. Other hematological and radiographic studies also indicate deficiencies in iron and vitamins A, B12, B6, and B9 (Rivera and Mirazón Lahr 2017). This sort of bone modification can result from any combination of inadequate diet, a heavy reliance on maize, poor sanitation, diarrhea, intestinal parasites, infectious disease, cultural practices related to breastfeeding in childhood, or even in utero conditions (Walker et al. 2009). The frequency of porotic hyperostosis in Maya samples varies (e.g., subadults versus adults, core versus periphery), but its presence

Table 1. Radiocarbon Dates, Location, and Sample Information.

\begin{tabular}{|c|c|c|c|}
\hline Radiocarbon Sample & Location of Sample Collection & Type of Sample & Date \\
\hline YU4124; $1286 \pm 20 \mathrm{BP}$ & Near the femur & Wood charcoal & cal AD $669-769$ at $2 \sigma$ \\
\hline AA $95401 ; 1311 \pm 37 \mathrm{BP}$ & Charcoal on the slabs of the cist & Wood charcoal & cal AD $653-770$ at $2 \sigma$ \\
\hline AA95405; $1820 \pm 100 \mathrm{BP}$ & Femur & Small proportion of collagen $(0.2 \%)^{\mathrm{a}}$ & N/A \\
\hline
\end{tabular}

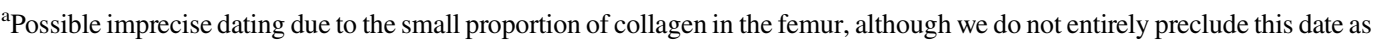
valid (Oxcal v. 4.3.2; Ramsey 2017; Reimer et al. 2013). 


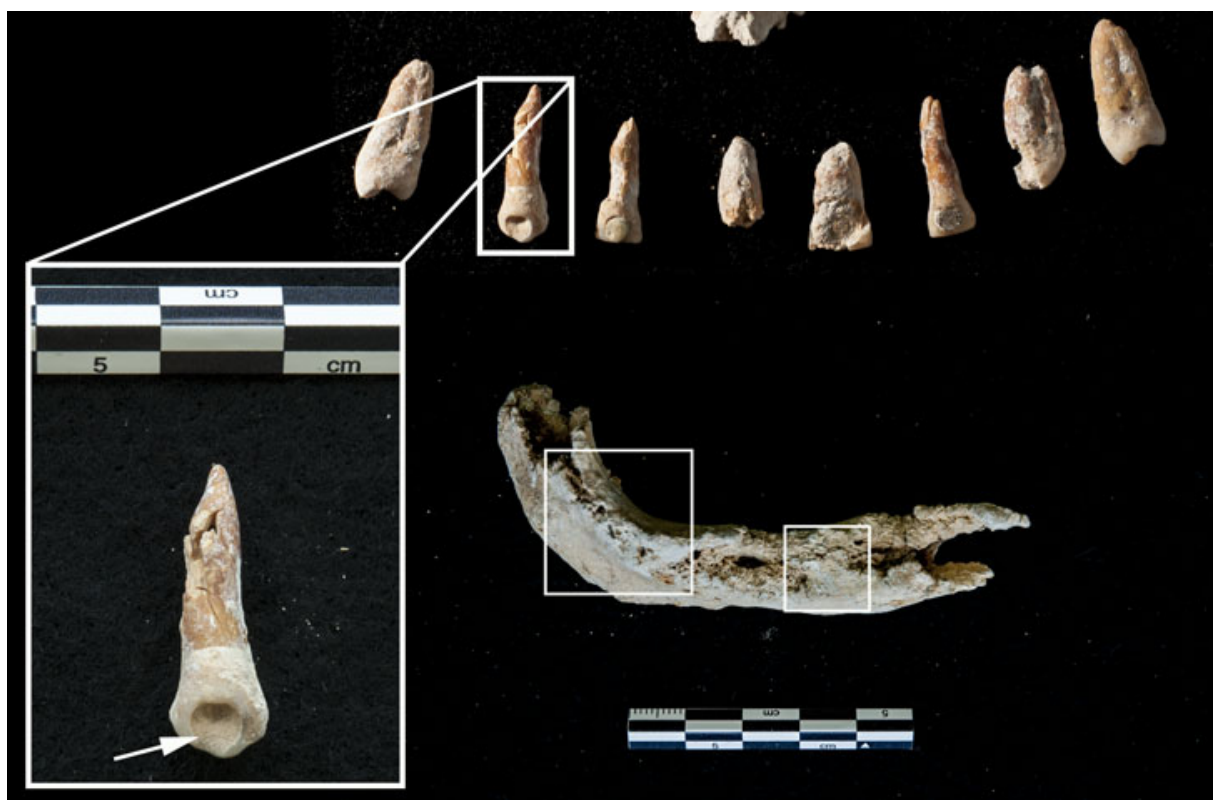

Figure 6. Mandible with antemortem loss of teeth and extensive alveolar reabsorption, calculus on maxillary right canine (\#6), and dental modifications. (Color online)

is common at low rates in sites such as Cuello, Iximché, Lamanai, and Tipu and at high rates in sites such as Chichén Itzá and Copán (e.g., Chase 1997; Cohen et al. 1997; Geller 2012; Hooton 1940; Saul 1972; Saul and Saul 1989; Storey et al. 2002; Wright 1994).
Although it is difficult to ascertain definitively what role the environment played in the health of the people at El Palmar and what specific social circumstances contributed to the compromised health conditions of the individual in Burial 1, the presence of porotic hyperostosis

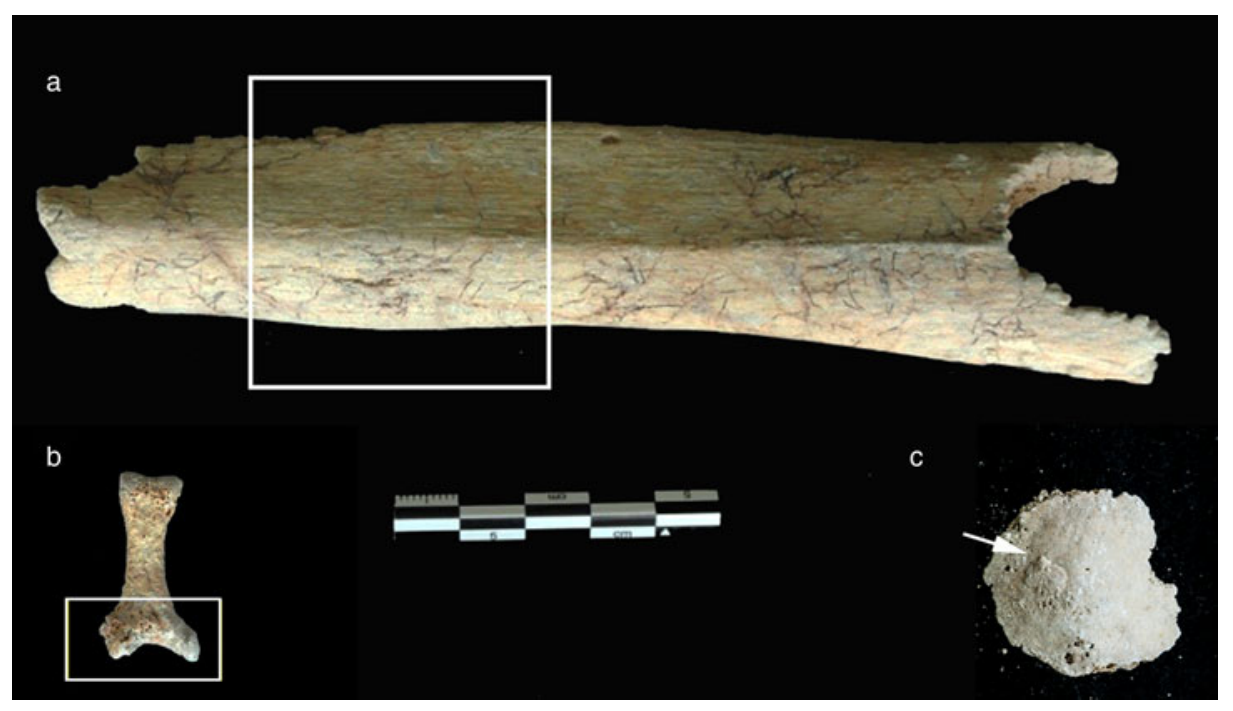

Figure 7. (a) Right tibia with healed fracture; (b) small deposits of bone in tarsal phalange; and (c) left patella small surface osteophyte. (Color online) 
sheds light on some of these matters. The condition in infancy resulted from a combination of the actions of the individual's caretakers and the cultural/environmental conditions of the social group in which this individual lived. Storey (1985) effectively suggests that urban centers in the Americas could have experienced problems of public sanitation and hygiene. Tropical environments provide a potential home for several endemic diseases, and parasitic infection is frequently increased by higher population density. Danforth (1997) suggests that Late Classic Maya sites could have regularly faced sanitary problems and inadequate diets, conditions that probably existed at times at El Palmar.

At a broader level, the political environment around El Palmar was unstable during the Classic period. Epigraphic evidence indicates that the nearby powerful dynasties of Tikal and Snake/ Calakmul shared intense and long-term rivalries during the period between about AD 378 and 736 (Martin and Grube 2008), creating unstable social circumstances in the region. The instability in the region likely affected the health of the individual found in Burial 1, starting in early infancy and continuing throughout his life.

During infancy, caregivers modified the skull of the Burial 1 individual and permanently influenced how he looked in life. There is no evidence to indicate that cephalic modifications were a marker of social position (Tiesler 1999, 2014), with the exception of superior head flattening - a type of modification achieved by either using cradleboards or cephalic devices - which is commonly found in association with opulent funeral attire linked to the elites (Tiesler 2014). Tiesler and Zabala (2017:282) mention that "head shaping is generation-bridging to signalize enduring social identities, physical embodiment, and long-standing ideas on the body and childrearing" (see also Duncan and Hofling 2011; Tiesler 2014). They also suggest that head shape would have acted as a visible sign of outer and inner beauty (Tiesler and Zabala 2017). Although the cultural meaning of cranial modification was probably polysemic, based on the modest funeral attire and the specific head shaping of the individual in Burial 1, the cranial modification likely emphasized a combination of the individual caregivers' group identity(ies) and their ideas about beauty and the body, childrearing, and ideology and was not related to sociopolitical status.

At some point during puberty or as a young adult, the individual acquired jade and pyrite inlays in his teeth that resulted in lifelong social and health consequences. Dental inlays are commonly found among individuals buried at centers associated with ruling elites (Eppich 2007, 2017; Romero Molina 1970; Tiesler et al. 2017; Williams and White 2006). For example, excavations at the el Perú-Waka' site revealed the presence of powerful nobles (Eppich 2007, 2017). One of the el Perú-Waka' individuals shows similar dental inlays to the individual at El Palmar. Dental inlays were also found on an individual of elevated status from Chan Chich (Geller 2006). At the site of Dos Hombres, a stone-lined tomb dating from the Early Classic (ca. AD 250-550) contained two socially prominent individuals who had type Romero E1 hematite inlays in their maxillary teeth (Geller 2006, 2014), similar to the individual from El Palmar.

The dental inlays took three to four steps to complete and required a skilled craftsperson with time and access to rare materials (Fastlicht 1971; Fastlicht and Romero Molina 1951; Mata Amado 1993; Ramírez et al. 2003; Tiesler 2000). Researchers argue that dental inlays in Classic Maya society were a sign of higher social status, preferentially performed among elites who lived in the urban core of the Maya Lowlands (Geller 2004; Sharer 1978; Tiesler 2014; Tiesler et al. 2017). Dental procedures probably occurred during or after puberty, as inlays are infrequently found in subadults (Braswell and Pitcavage 2009; Mayer 1983; Plumer 2017; Romero Molina 1958). Teeth alterations were probably part of a rite of initiation that occurred when a person received some charge or office that in many cases was related to religion and ideology (López-Olivares 1997). Joyce (2002) and Geller (2006) suggest that in Maya society individuals embodied their different identities through clothing and body modification.

Dental modification likely involved pain if the drilling exposed the dentine (Geller 2006). The dentine contains many microscopic tubules with fluids; depending on the size and number 
of these tubules, pain and tooth sensitivity can be triggered (van Loveren 2013). Geller (2006) argues that this modification facilitated an identity change through an initiation ritual associated with becoming part of a group that shared the same experience. People in other societies also modified their teeth as a part of rites of passage into adulthood (Artaria 2017; de Groote and Humphrey 2017). Dental modifications were probably regulated by group membership and served as adornments to increase individual beauty and impart social distinction (Tiesler et al. 2017).

The individual in our sample was subjected to the dental procedure at least six times, suggesting his frequent endurance of short-term pain. These dental procedures were related to significant social events and changes in his life history. Perhaps they marked his inclusion and full participation into a more select group such as the lakam elites in the El Palmar dynasty or welcomed him to the broader social group as an adult. These physical changes are a clear manifestation of the fluidity in an individual's social identity throughout his life. The dental modifications were highly visible in face-to-face interactions when the individual spoke and opened his mouth, signaling to others his different status and identity. In addition, the raw material from one of the inlays, jade, is commonly associated with elites and was highly controlled (Taube 2005).

Small round inlays were applied to the teeth of the individual, but only two still hold the stone pieces. The rest of the pieces were lost either antemortem or postmortem. The dental inlays probably had long-term health consequences, which may not have been noticed in life by the individual. The first right maxillary incisor has hypercementosis, an idiopathic condition characterized by abnormal growth of the cementum at the root of the tooth (Aufderheide and Rodríguez-Martin 1998; Bürklein et al. 2012; Ortner 2003). This incisor had been partially drilled with a small round piece of stone placed inside the hole.

Long before the individual died, this person experienced extensive antemortem tooth loss on the left side of the mandible, indicated by the presence of extensive alveolar reabsorption in this area. None of these dental issues seem to be related to the inlays. Antemortem tooth loss probably affected some aspects of his life, creating challenges to chewing hard food with the left side of the mouth. There was also a possible abscess on the first mandibular lower right premolar that likely caused pain, in addition to a moderate accumulation of dental calculus, a hardened form of plaque.

The man in Burial 1 experienced other health problems throughout his life, including a fractured right tibia from which he had recovered years before death. We cannot determine whether this was a result of an accident or a violent encounter, but we do know that this kind of fracture is often seen today in contact sports such as rugby, football, and soccer (Emami et al. 1996; Praemer et al. 1992; Schmidt et al. 2003). The iconographic representation of ballplayers on the Guzmán stairway suggests that members of the lakam participated in or witnessed ballgames, but no additional evidence connects this injury specifically to ballgame activities. Ballgames were common and visible public events among the Classic Maya with a risk of injury, entangling sacrifices and power (e.g., Cohodas 1991; Stoll and Anderson 2017).

$\mathrm{He}$ also had healed periostitis on the radii. Periostitis, which results in some tenderness and aching pain in the afflicted area (Aufderheide and Rodríguez-Martin 1998; Ortner 2003), is commonly caused by nonspecific bacterial infection, trauma, tuberculosis, or metabolic disorders like scurvy and rickets (Novak et al. 2017; Ortner 2003; Weston 2012). No evidence of tuberculosis or rickets was observed elsewhere. As he aged, light to moderate degenerative joint disease (DJD) developed in the articulations of the right elbow, hands, left knee, left ankle, and feet (Aufdeheide and Rodríguez-Martin 1998; Ortner 2003). DJD has been observed in Maya areas, especially in individuals of higher socioeconomic status associated with crafting and specialized labor (Plumer 2017). Individuals with DJD experience pain and stiffness around the affected areas, particularly after periods of inactivity or in the mornings, and the pain often increases in intensity with age (e.g., Sharma 2016; Wesseling et al. 2015).

DJD has a multifactorial etiology and can be associated with obesity, repeated mechanical stress to a joint, and age (Rogers and Waldron 
1995; Weiss and Jurmain 2007). The DJD observed in his hand and elbow joints could be evidence of different activities and manual labor, possibly a result of the tasks performed by standard-bearers with their hands. His role as a banner-bearer in life was embodied in his body. Creating and carrying a shaft or pole representing the rulers of El Palmar for a long time and distance can undoubtedly create physiological stress in the joints. The DJD in the knees and ankles could be related to normal weight-bearing and aging (Zampetti et al. 2016), as well as activities that placed significantly more force on the knee by requiring frequent bending from ascending and descending stairs, crossing varied terrain, and hiking (Austin 2017; Jensen 2008; Komistek et al. 2005). If he was an ambassador or bannerbearer and therefore involved in a tributary role as part of the standard-bearers, it is likely that he frequently went up and down stairs and often walked shorter and longer distances over a wide range of terrains. The Central Karstic Upland in which El Palmar is located contains undulating landscapes that probably placed a burden on his body. Rice (2007) mentions that expeditions can also involve trading, pilgrimages, and chiefly legitimation rituals, among other activities, and were clearly part of elite culture, power, legitimation, and wealth.

Braswell (2003:302) stresses the political importance of Maya ambassadors who were engaged in long-distance travel to discuss political and trade issues. He mentions that Hernán Cortés's fourth letter to the Crown describes a meeting with a delegation from Kaqchikel in northern Veracruz seeking an alliance with the Spaniards against the K'iche'. Additionally, a possible lolmay or lolmet, the K'iche name for ambassador, visited the Aztecs in Xoconochco for political reasons (Braswell 2003:302). These historical narratives accord well with the inscriptions of the Guzmán stairway at El Palmar, which commemorate the journey of Ajpach' Waal as an ambassador to Copán under the auspice of Calakmul's Snake Dynasty.

The osteobiography of the individual suggests that his status changed during his life. Close to his death around AD 726, when the Snake Dynasty attempted to ally with Copán through El Palmar, the economic and sociopolitical conditions of the individual interred in Burial 1 seem to have changed. He lost a dental inlay that was not replaced. We were able to identify that the decorative piece in the right maxillary canine was lost antemortem, because the circular orifice of enamel contains a moderate amount of calculus (Figure 6). Replacing a decorative piece was probably important for maintaining the status of the person in face-to-face interactions; thus, it is possible that this antemortem loss signified a change in his status before death. The modest offering of only two polychrome vessels could indicate moderate wealth for Individual 1, given that highstatus burials usually contain more elaborate offerings in Classic Maya society (Chase 1992; Coe 1988; Haviland and Moholy-Nagy 1992; Tiesler and Cucina 2006; Weiss-Krejci 2011). There are some exceptions, of course, as in the case of Piedras Negras (see Plumer 2017; Scherer 2015) and Río Bec, an archaeological site close to El Palmar where grave construction does not correlate with social hierarchy (Pereira 2013).

Burials in the Maya area are usually found within household structures (Chase and Chase 1996; Plumer 2017). The individuals buried within the structures were most likely the owner of the residence, important household members, or other distinguished relatives (McAnany 1995, 1998; Weiss-Krejci 2011). The placement of the individual in Temple GZ1 attests to his sociopolitical importance among lakam elites. The mourners carefully placed the body of the individual, along with polychrome vessels, in a cist that had been cut into the plaster floor of Structure GZ1. His placement under the floor in close connection to the living provides a direct link to and constant reminder of this individual, his lineage, and collective group histories. The burial was closed with slabs, and a fire ritual was performed on top of the cist. Cists and slabs placed in cists have been found at other Maya sites (Brady and Ashmore 1999; Pereira 2013) and are symbolically associated with caves and ideas about the underworld (Brady and Ashmore 1999; Pereira 2013). Traces of fire observed at the point of closure could link the dead with the house and honor the deceased (Fitzsimmons 2009; Pereira 2013). Thus, the fire ritual found in Burial 1 was tied to both the internment and the building ceremony of the hieroglyphic stairway. 
At the Guzmán Group, both archaeological evidence of the fire ritual and its iconographic representation on the offering vessel reinforce the sociopolitical importance of this person, probably embodying his various identities. The timing of the burial in conjunction with Ajpach' Waal's claim of the eastern temple in the texts suggests that the individual is either Ajpach' Waal himself or his father, Ajlu...Chih. There is no textual evidence from the burial offerings indicating the name and title of the person. Nonetheless, Ajpach' Waal is a strong candidate judging from his emphasis on his ownership of the temple and the entire group.

\section{Conclusions}

In this article, inspired by the life course and osteobiographical approaches, we explore who the individual found in Structure GZ1 was and what kind of experiences he had throughout life and death. Different lines of evidence suggest that the individual in Burial 1 experienced diverse social, political, and economic situations that constantly changed during his life and at his death. Living through periods of political turbulence, he must have experienced a wide array of events that shaped and reshaped his identities, affiliations, and sociopolitical status throughout his life course.

We consider the importance of fluidity in individual identities. These multiple intersecting identities are often challenging to extract from artifactual analyses, epigraphic studies, or osteological analysis alone. Combining diverse methods, however, sheds light on the formation and transformation of the variable identities of an individual. Our approach revealed a nonroyal elite member of Classic Maya society who was linked both to local internal politics and regional dynastic interactions. This person suffered a variety of diseases, injuries, and pain throughout his life. His kin were also likely concerned with beautification even when they were physically uncomfortable and underwent painful procedures such as cranial modification and dental inlays. Individual 1 probably frequently witnessed and was actively engaged in critical political events as a standard-bearer for El Palmar's royal elites. At the end of his life, he was buried and commemorated by members of his group in a unique carved monument that is regularly associated with royal elites in the Maya lowlands. Future studies of human remains from El Palmar will help incorporate this individual into more nuanced contexts regarding health, trauma, and physical appearance in this dynasty.

Acknowledgments. We want to thank the Consejo de Arqueología INAH; Centro INAH Campeche; Coordinación Nacional de Conservación del Patrimonio Cultural; Ejido Kiché Las Pailas, the codirector of the El Palmar Archaeological Project, Javier López Camacho; and the project crews for their support. Special thanks to Thomas Fenn, Matthew Pailes, Marc Levine, Marijke Stoll, Jessica Munson, and reviewers for their productive comments and suggestions for an early version of this article. This research was supported by awards to Tsukamoto from the National Science Foundation (BSC-111640) and the JSPS KAKENHI (15J00280, 19K13408, and 20H05141).

Data Availability Statement. All osteological inventories and field notes for this study are stored in the Bioarchaeology Laboratory, Department of Anthropology, University of Oklahoma, Norman, and the Department of Anthropology University of California, Riverside. All data are available upon request from the authors.

Supplemental Materials. For supplemental material accompanying this article, visit https://doi.org/10.1017/laq.2020.96.

Supplemental Text 1. Osteological Analysis.

\section{References Cited}

Agarwal, Sabrina C.

2012 The Past of Sex, Gender, and Health: Bioarchaeology of the Aging Skeleton. American Anthropologist 114:322-335.

Agarwal, Sabrina C., and Julie K. Wesp (editors)

2017 Exploring Sex and Gender in Bioarchaeology. University of New Mexico Press, Albuquerque.

Alfaro Castro, Martha Elena, Andrea L. Waters-Rist, and Danny Zborover

2017 An Osteobiography of a Oaxacan Late Adolescent Female. Journal of Archaeological Science: Reports 13:759-772.

Arizona State Museum

2018 ASM Osteology Recording Packet. Cultural Resource Services Forms \& Guidelines. Arizona State Museum, University of Arizona, Tucson. Electronic document, https://statemuseum.arizona.edu/file/712, accessed August 28, 2019.

Artaria, Myrtati

2017 Tooth Filling in Surabayan Javanese and Balinese: A Change in Tradition. In A World View of Bioculturally Modified Teeth, edited by Scott E. Burnett and Joel D. Irish, pp. 182-192. University Press of Florida, Gainesville.

Aufderheide, Arthur C., and Conrado Rodríguez-Martin 1998 The Cambridge Encyclopedia of Human Paleopathology. Cambridge University Press, Cambridge. 
Austin, Anne E.

2017 The Cost of a Commute: A Multidisciplinary Approach to Osteoarthritis in New Kingdom Egypt. International Journal of Osteoarchaeology 27:537-550.

Beauchesne, Patrick, and Sabrina C. Agarwal (editors)

2018 Children and Childhood in Bioarchaeology. University Press of Florida, Gainesville.

Becker, Marshall Joseph

1991 Plaza Plans at Tikal, Guatemala, and at Other Lowland Maya Sites: Evidence for Patterns of Cultural Change. Centro de Arquitectura Mesoamericana $14: 11-26$.

Brady, James E., and Wendy Ashmore

1999 Mountains, Caves, Water: Ideational Landscapes of the Ancient Maya. In Archaeologies of Landscapes: Contemporary Perspectives, edited by Wendy Ashmore and A. Bernard Knapp, pp. 124-145. Blackwell, Oxford.

Braswell, Geoffrey E.

2003 K'iche'an Origins, Symbolic Emulation, and Ethnogenesis in the Maya Highlands: A.D. 1400-1524. In The Postclassic Mesoamerican World, edited by Michael E. Smith and Frances F. Berdan, pp. 297-303. University of Utah Press, Salt Lake City.

Braswell, Geoffrey E., and Megan R. Pitcavage

2009 The Cultural Modification of Teeth by the Ancient Maya: A Unique Example from Pusilha, Belize. Mexicon 31:24-27.

Buikstra, Jane E.

2006 Section II Emerging Specialties. In Bioarchaeology: The Contextual Analysis of Human Remains, edited by Jane E. Buikstra and Lane A. Beck, pp. 195-205. Elsevier, Amsterdam.

Buikstra, Jane E., and Rachel E. Scott

2009 Key Concepts in Identity Studies. In Bioarchaeology and Identity in the Americas, edited by Kelly J. Knudson and Christopher M. Stojanowski, pp. 2455. University Press of Florida, Gainesville.

Buikstra, Jane E., and Douglas Ubelaker

1994 Standards for Data Collection from Human Skeletal Remains: Proceedings of a Seminar at the Field Museum of Natural History. Research Series No. 44. Arkansas Archaeological Survey, Fayetteville.

Bürklein, Sebastian, Sabine Jansen, and Edgard Schäfer

2012 Occurrence of Hypercementosis in a German Population. Journal of Endodontics 38:1610-1612.

Byrnes, Jennifer F., and Jennifer Lynn Muller (editors)

2017 Bioarchaeology of Impairment and Disability: Theoretical, Ethnohistorical, and Methodological Perspectives. Springer International, Cham, Switzerland.

Chase, Diane Z.

1992 Postclassic Maya Elites: Ethnohistory and Archaeology. In Mesoamerican Elites: An Archaeological Assessment, edited by Diane Z. Chase and Arlen F. Chase, pp. 124-135. University of Oklahoma Press, Norman.

1997 Human Osteology, Pathology, and Demography as Represented in the Burials of Caracol, Belize. In Investigations at the Classic Maya City of Caracol, Belize: 1985-1987, edited by Arlen F. Chase and Diane Z. Chase, pp. 123-138. Pre-Columbian Art Research Institute, San Francisco.

Chase, Diane Z., and Arlen F. Chase

1996 Maya Multiples: Individuals, Entries, and Tombs in
Structure A34 of Caracol, Belize. Latin American Antiquity 7:61-79.

2004 Hermeneutics, Transitions, and Transformations in Classic to Postclassic Maya Society. In The Terminal Classic in the Maya Lowlands: Collapse, Transition, and Transformation, edited by Arthur A. Demarest, Prudence M. Rice, and Don S. Rice, pp. 12-27. University Press of Colorado, Boulder.

Coe, Michael D.

1988 Ideology of the Maya Tomb. In Maya Iconography, edited by Elizabeth P. Benson and Gillett G. Griffin, pp. 222-235. Princeton University Press, Princeton, New Jersey.

Cohen, Mark N., Kathleen O’Connor, Marie Elaine Danforth, Keith P. Jacobi, and Carl Armstrong

1997 Archaeology and Osteology of the Tipu Site. In Bones of the Maya: Studies of Skeletons, edited by Stephen L. Whittington and David M. Reed, pp. 78-88. Smithsonian Institution, Washington, DC.

Cohodas, Marvin

1991 Ballgame Imagery of the Maya Lowlands: History and Iconography. In The Mesoamerican Ballgame, edited by Vernon L. Scarborough and David R. Wilcox, pp. 251-288. University of Arizona Press, Tucson.

Danforth, Marie Elaine

1997 Late Classic Maya Health Patterns: Evidence from Enamel Microdefects. In Bones of the Maya: Studies of Skeletons, edited by Stephen L. Whittington and David M. Reed, pp. 127-137. Smithsonian Institution, Washington, DC.

de Groote, Isabelle, and Louise T. Humphrey

2017 The Chronology and Significance of Ablation in the Later Stone Age Maghreb. In A World View of Bioculturally Modified Teeth, edited by Scott E. Burnett and Joel D. Irish, pp. 19-32. University Press of Florida, Gainesville.

Duday, Henri

2009 The Archaeology of the Death: Lectures in Archaeothanatology. Translated by Anna Maria Ciprian and John Pearce. Oxbow Books, Oxford.

Duncan, William N., and Charles A. Hofling

2011 Why the Head? Cranial Modification as Protection and Ensoulment among the Maya. Ancient Mesoamerica 22:199-210.

Elder, Glen H., Monica Kirkpatrick Johnson, and Robert Crosnoe

2004 The Emergence and Development of Life Course Theory. In Handbook of the Life Course, edited by Jeylan T. Mortimer and Michael J. Shanahan, pp. 3-19. Springer, New York.

Emami, Abbas, Bengt Mjöberg, Bjöm Ragnarsson, and Sune Larsson

1996 Changing Epidemiology of Tibial Shaft Fractures: 513 Cases Compared between 1971-1975 and 1986-1990. Acta Orthopaedica Scandinavica 67:557-561.

Eppich, Keith

2007 Death and Veneration at El Perú-Waka': Structure M14-15 as Ancestor Shrine. PARI Journal 8(1):1-16.

2017 The Last Palace: Stones, Bones, and Feasts, Recent Excavations at El Perú-Waka', Guatemala. Paper presented at the 8th Annual South-Central Conference on Mesoamerica, New Orleans, Louisiana. Electronic document, https://www.academia.edu/35401569/Eppich 2017_SCCM_The_Last_Palace_with_Text_pdf, accessed November 16, 2020. 
Esparza Olguín, Octavio Q., and Kenichiro Tsukamoto

2011 Espacios de la escenografía ritual. In Los Mayas: Voces de piedra, edited by Alejandra Martínez de Velasco and María Elena Vega, pp. 393-399. Ámbar Diseño, Mexico City.

Fastlicht, Samuel

1971 La odontología en el México prehispánico. Edimex, Mexico City.

Fastlicht, Samuel, and Javier Romero Molina

1951 El arte de las mutilaciones dentarias. Enciclopedia Mexicana del arte 14. Ediciones Mexicanas, Mexico City.

Fisher, Genevieve, and Diana DiPaolo Loren

2003 Embodying Identities in Archaeology. Cambridge Archaeological Journal 13:225-261.

Fitzsimmons, James L.

2009 Death and the Classic Maya Kings. University of Texas Press, Austin.

Geller, Pamela L.

2004 Transforming Bodies, Transforming Identities: A Consideration of Pre-Columbian Maya Corporeal Beliefs and Practices (Belize). PhD dissertation, Department of Anthropology, University of Pennsylvania, Philadelphia.

2006 Altering Identities: Body Modifications and the PreColumbian Maya. In Social Archaeology of Funerary Remains, edited by Rebecca Gowland and Christopher Knüsel, pp. 279-291. Oxbow Books, Oxford.

2009 Bodyscapes, Biology, and Heteronormativity. American Anthropologist 111:504-516.

2012 Parting (with) the Dead: Body Partibility as Evidence of Commoner Ancestor Veneration. Ancient Mesoamerica 23:115-130.

2014 Sedimenting Social Identity: The Practice of PreColumbian Maya Body Partibility. In The Bioarchaeology of Space and Place: Ideology, Power, and Meaning in Maya Mortuary Contexts, edited by Gabriel D. Wrobel, pp. 15-38. Springer, New York.

2018 Bioarchaeology of Socio-Sexual Lives: Queering Common Sense about Sex, Gender, and Sexuality. Springer International, Cham, Switzerland.

Geller, Pamela L., and Miranda Stockett Suri

2014 Relationality, Corporeality and Bioarchaeology: Bodies qua Bodies, Bodies in Context. Cambridge Archaeological Journal 24:499-512.

Gilchrist, Roberta

1999 Gender and Archaeology: Contesting the Past. Routledge, London.

2000 Archaeological Biographies: Realizing Human Lifecycles, Courses, and Histories. World Archaeology 31:325-328.

2012 Medieval Life: Archaeology and the Life Course. Boydell Press, Woodbridge, UK.

Glencross, Bonnie A.

2011 Skeletal Injury across the Life Course: Towards Understanding Social Agency. In Social Bioarchaeology, edited by Sabrina C. Agarwal and Bonnie A. Glencross, pp. 390-409. Wiley-Blackwell, Chichester, UK.

Gowland, Rebecca L.

2006 Ageing the Past: Examining Age Identity from Funerary Evidence. In Social Archaeology of Funerary Remains, edited by Rebecca L. Gowland and Christopher Knüsel, pp. 143-153. Alden Press, Oxford.

Grosman, Leore, Natalie D. Munro, and Anna Belfer-Cohen

2008 A 12,000-Year-Old Shaman Burial from the Southern Levant (Israel). PNAS 105:17665-17669.
Haviland, William A., and Hattula Moholy-Nagy

1992 Distinguishing the High and Mighty from the Hoi Polloi at Tikal, Guatemala. In Mesoamerican Elites: An Archaeological Assessment, edited by Diane Z. Chase and Arlen F. Chase, pp. 39-48. University of Oklahoma Press, Norman.

Hawkey, Diane E.

1998 Disability, Compassion, and the Skeletal Record: Using Musculoskeletal Stress Markers (MSM) to Construct an Osteobiography from Early New Mexico. International Journal of Osteoarchaeology 8:326-340.

Helmke, Christophe, and Jaime J. Awe

2016 Sharper than a Serpent's Tooth: A Tale of the SnakeHead Dynasty as Recounted on Xunantunich Panel 14. PARI Journal 17(2):1-22.

Hollimon, Sandra E.

2017 Bioarchaeological Approaches to Nonbinary Genders: Case Studies from Native North America. In Exploring Sex and Gender in Bioarchaeology, edited by Sabrina C. Agarwal and Julie K. Wesp, pp. 51-69. University of New Mexico Press, Albuquerque.

Hooton, Ernest Albert

1940 Skeletons from the Cenote at Chichen Itza. In The Maya and their Neighbors, edited by Clarence Leonard Hay, Ralph L. Linton, Samuel K. Lothrop, Harry L. Shapiro, and George C. Vaillant, pp. 272280. Appleton-Century-Crofts, New York.

Houston, Stephen D., and David Stuart

2001 Peopling the Classic Maya Court. In Royal Courts of the Ancient Maya, Vol. 1: Theory, Comparison, and Synthesis, edited by Takeshi Inomata and Stephen D. Houston, pp. 54-83. Westview Press, Boulder, Colorado.

Inglis, Raelene M., and Siân E. Halcrow

2018 The Bioarchaeology of Childhood: Theoretical Development in the Field. In Children and Childhood in Bioarchaeology, edited by Patrick Beauchesne and Sabrina C. Agarwal, pp. 33-60. University Press of Florida, Gainesville.

Jensen, Lilli Kirkeskov

2008 Knee Osteoarthritis: Influence of Work Involving Heavy Lifting, Kneeling, Climbing Stairs or Ladders, or Kneeling/Squatting Combined with Heavy Lifting. Occupational and Environmental Medicine 65:72.

Joyce, Rosemary A.

2001 Burying the Dead at Tlatilco: Social Memory and Social Identities. In Social Memory, Identity, and Death: Anthropological Perspectives on Mortuary Rituals, edited by Meredith S. Chesson, pp. 12-26. Archaeological Papers Vol. 10. American Anthropological Association, Arlington, Virginia.

2002 Beauty, Sexuality, Body Ornamentation, and Gender in Ancient Meso-America. In Pursuit of Gender: Worldwide Archaeological Approaches, edited by Sarah M. Nelson and Myriam Rosen-Ayalon, pp. 8191. AltaMira Press, Walnut Creek, California.

2005 Archaeology of the Body. Annual Review of Anthropology 34:139-158.

Kerr, Justin

1998 The Maya Vase Book: A Corpus of Rollout Photographs of Maya Vases Vol. 1. Kerr Associates, New York.

Knudson, Kelly J., and Christopher M. Stojanowski

2008 New Directions in Bioarchaeology: Recent Contributions to the Study of Human Social Identities. Journal of Anthropological Research 16:397-342.

Komistek, Richard D., Thomas R. Kane, Mohamed Mahfouz, Jorge A. Ochoa, and Douglas A. Dennis 
2005 Knee Mechanics: A Review of Past and Present Techniques to Determine in vivo Loads. Journal of Biomechanics 38:215-228.

Krogman, Wilson Marion

1935 Life Histories Recorded in Skeletons. American Anthropologist 37:92-103.

Lacadena, Alfonso

2008 El título Lakam: Evidencia epigráfica sobre la organización tributaria y militar interna de los reinos Mayas del Clásico. Mayab 20:23-43.

Lessa, Andrea, and Niéde Guidon

2002 Osteobiographic Analysis of Skeleton I, Sitio Toca dos Coqueiros, Serra da Capivara National Park, Brazil, 11,060 BP: First Results. American Journal of Physical Anthropology 118:99-110.

López-Olivares, Nora M.

1997 Cultural Odontology: Dental Alterations from Petén, Guatemala. In Bones of the Maya: Studies of Ancient Skeletons, edited by Stephen L. Whittington and David M. Reed, pp. 105-116. Smithsonian Institution, Washington, DC.

Martin, Simon, and Nikolai Grube

2008 Chronicle of the Maya Kings and Queens: Deciphering the Dynasties of the Ancient Maya. Thames \& Hudson, London.

Martin, Simon, and Erik Velásquez García

2016 Polities and Places: Tracing the Toponyms of the Snake Dynasty. PARI Journal 17(2):23-33.

Mata Amado, Guillermo

1993 Odontología Prehispánica en Mesoamérica. Anales de la Academia de Geografía e Historia de Guatemala 67:177-209.

Mayer, Karl Herbert

1983 Dental Decoration among the Pre-Columbian Maya. Organorama 20:15-20.

Mayes, Arion T., and Sarah B. Barber

2008 Osteobiography of a High-Status Burial from the Lower Río Verde Valley of Oaxaca, Mexico. International Journal of Osteoarchaeology 18:573-588.

McAnany, Patricia

1995 Living with Ancestors: Kingship and Kinship in Ancient Maya Society. University of Texas Press, Austin.

1998 Ancestors and the Classic Maya Built Environment. In Function and Meaning in Classic Maya Architecture, edited by Stephen D. Houston, pp. 271-298. Dumbarton Oaks, Washington, DC.

McClelland, John, and Jessica I. Cerezo-Román

2016 Personhood and Re-Embodiment in Osteological Practice. In Dealing with the Dead: Mortuary Archaeology and Contemporary Society, edited by Melanie Giles and Howard Williams, pp. 39-67. Oxford University Press, Oxford.

Meskell, Lynn

1999 Archaeologies of Social Life: Age, Sex, Class et cetera in Ancient Egypt. Blackwell, Oxford.

Meskell, Lynn M., and Rosemary A. Joyce

2003 Embodied Lives Figuring Ancient Maya and Egyptian Experience. Routledge, London.

Novak, Mario, Rachel Howcroft, and Ron Pinhasi

2017 Child Health in Five Early Medieval Irish Sites: A Multidisciplinary Approach. International Journal of Osteoarchaeology 27:398-408.

Ortner, Donald J.

2003 Identification of Pathological Conditions in Human Skeletal Remains. 2nd ed. Academic Press, San Diego.
Ortner, Donald J., Whitney Butler, Jessica Cafarella, and Lauren Milligan

2001 Evidence of Probable Scurvy in Subadults from Archeological Sites in North America. American Journal of Physical Anthropology 114:343-351.

Ortner, Donald J., and Mary Frances Ericksen

1997 Bone Changes in the Human Skull Probably Resulting from Scurvy in Infancy and Childhood. International Journal of Osteoarchaeology 7:212-220.

Palka, Joel W.

2014 Maya Pilgrimage to Ritual Landscapes: Insights from Archaeology, History, and Ethnography. University of New Mexico Press, Albuquerque.

Pereira, Grégory

2013 Ash, Dirt, and Rock: Burial Practices at Río Bec. Ancient Mesoamerica 24:449-468.

Perry, Elizabeth, and Rosemary Joyce

2001 Providing a Past for "Bodies that Matter": Judith Butler's Impact on the Archaeology of Gender. International Journal of Sexuality and Gender Studies 6:63-76.

Plumer, Hannah

2017 Health among the Maya: An Osteoarchaeological Comparison of Sites in the Northern Three Rivers Region, Belize. BAR International Series 2879. British Archaeological Reports, Oxford.

Praemer, Allan, Sylvia Furner, and Dorothy P. Rice

1992 Musculoskeletal Conditions in the United States. American Academy of Orthopaedic Surgeons, Park Ridge, Illinois.

Ramírez Salomón, Marco, Vera Tiesler, Iván Olivia Arias, and Guillermo Mata Amado

2003 Posibles técnicas empleadas en la decoración dental en la Mesoamérica Prehispánica: Un estudio experimental de instrumentos y superficies. Estudios de antropología biológica 2:983-998.

Ramsey, Christopher Bronk

2017 Methods for Summarizing Radiocarbon Datasets. Radiocarbon 59:1809-1833.

Reimer, Paula J., Edouard Bard, Alex Bayliss, J. Warren Beck, Paul G. Blackwell, Christopher Bronk Ramsey, Caitlin E. Buck, Hai Cheng, R. Lawrence Edwards, Michael Friedrich, Pieter M. Grootes, Thomas P. Guilderson, Haflidi Haflidason, Irka Hajdas, Christine Hatté, Timothy J. Heaton, Dirk L. Hoffmann, Alan G. Hogg, Konrad A. Hughen, K. Felix Kaiser, Bernd Kromer, Sturt W. Manning, Mu Niu, Ron W. Reimer, David A. Richards, E. Marian Scott, John R. Southon, Richard A. Staff, Christian S. M. Turney, and Johannes van der Plicht

2013 IntCal13 and Marine13 Radiocarbon Age Calibration Curves 0-50,000 Years cal BP. Radiocarbon 55:18691887.

Rice, Prudence M.

2007 Maya Calendar Origins Monuments, Mythistory, and the Materialization of Time. University of Texas Press, Austin.

Rivera, Frances, and Marta Mirazón Lahr

2017 New Evidence Suggesting a Dissociated Etiology for Cribra Orbitalia and Porotic Hyperostosis. American Journal of Physical Anthropology 164:76-96.

Robb, John

2002 Time and Biography: Osteobiography of the Italian Neolithic Lifespan. In Thinking through the Body: Archaeologies of Corporeality, edited by Yannis Hamilakis, Mark Pluciennik, and Sarah Tarlow, pp. 153-171. Academic/Plenum, New York. 
Roberts, Charlotte

1999 Disability in the Skeletal Record: Assumptions, Problems, and Some Examples. Archaeological Method and Theory 15:79-97.

Rogers, Juliet, and Tony Waldron

1995 A Field Guide to Joint Disease in Archaeology. John Wiley \& Sons, New York.

Romero Molina, Javier

1958 Mutilaciones dentarias, prehispánicas de México y América en general. Instituto Nacional de Antropología e Historia, Mexico City.

1970 Dental Mutilation, Trephination and Cranial Deformation. In Physical Anthropology, edited by Thomas Stewart, pp. 50-67. Handbook of Middle American Indians, Vol. 9, Robert Wauchope, general editor. University of Texas Press, Austin.

Saul, Frank P.

1972 The Human Skeletal Remains of Altar de Sacrificios: An Osteobiographic Analysis. Papers of the Peabody Museum of Archaeology and Ethnology Vol. 63, No. 2. Harvard University, Cambridge, Massachusetts.

Saul, Frank P., and Julie M. Saul

1989 Osteobiography: A Maya Example. In Reconstruction of Life from the Skeleton, edited by Mehmet Yasar İşcan and Kenneth A. R. Kennedy, pp. 287-302. Alan R. Liss, New York.

Schele, Linda, and Mary Ellen Miller

1986 The Blood of Kings: Dynasty and Ritual in Maya Art. Kimbell Art Museum, Fort Worth, Texas.

Scherer, Andrew K.

2015 Mortuary Landscapes of the Classic Maya: Rituals of Body and Soul. University of Texas Press, Austin.

Schmidt, Andrew H., Christopher G. Finkemeier, and Paul Tornetta

2003 Treatment of Closed Tibial Fractures. Instructional Course Lectures 52:607-622.

Sharer, Robert J.

1978 Archaeology and History at Quirigua, Guatemala. Journal of Field Archaeology 5:51-70.

Sharma, Leena

2016 Osteoarthritis Year in Review 2015: Clinical. Osteoarthritis Cartilage 24:36-48.

Sofaer, Joanna R.

2006 The Body as Material Culture: A Theoretical Osteoarchaeology. Cambridge University Press, Cambridge.

Stodder, Ann, and Ann M. Palkovich (editors)

2012 The Bioarchaeology of Individuals. University Press of Florida, Gainesville.

Stoll, Marijke, and David S. Anderson

2017 Sport and Ritual as Social Bonding: The Communal Nature of Mesoamerican Ballgames. In Prehistoric Games of North American Indians: Subarctic to Mesoamerica, edited by Barbara Voorhies, pp. 447-482. University of Utah Press, Salt Lake City.

Storey, Rebecca

1985 An Estimate of Mortality in a Pre-Columbian Urban Population. American Anthropologist 87:519-534.

Storey, Rebeca, Lourdes Márquez, and Vernon Schmidt

2002 Social Disruption and the Maya Civilization of Mesoamerica: A Study of Health and Economy of the Last Thousand Years. In The Backbone of History: Health and Nutrition in the Western Hemisphere, edited by Richard H. Steckel and Jerome C. Rose, pp. 281306. Cambridge University Press, New York.
Stuart, David

2010 The LAKAM Logograph. Maya Decipherment: Ideas on Ancient Maya Writing and Iconography (blog), March 8. http://decipherment.wordpress.com/ 2010/03/08/the-lakam-logogram, accessed July 5, 2012.

Taube, Karl

2005 The Symbolism of Jade in Classic Maya Religion. Ancient Mesoamerica 16:23-50.

Tiesler, Vera

1999 Rasgos bioculturales entre los antiguos Mayas: Aspectos arqueológicos y sociales. $\mathrm{PhD}$ dissertation, Facultad de Filosofía y Letras, Universidad Nacional Autónoma de México, Mexico City.

2000 Decoraciones dentales de los antiguos Mayas. Ediciones Euroamericanas/INAH, Mexico City.

2014 The Bioarchaeology of Artificial Cranial Modifications: New Approaches to Head Shaping and its Meanings in Pre-Columbian Mesoamerica and Beyond. Springer, New York.

Tiesler, Vera, and Andrea Cucina (editors)

2006 Janaab' Pakal of Palenque: Reconstructing the Life and Death of a Maya Ruler. University of Arizona Press, Tucson.

Tiesler, Vera, Andrea Cucina, and Marco Ramírez-Salomon 2017 Permanent Dental Modifications among the Ancient Maya: Procedures, Health Risks, and Social Identities. In A World View of Bioculturally Modified Teeth, edited by Scott E. Burnett and Joel D. Irish, pp. 270-284. University Press of Florida, Gainesville.

Tiesler, Vera, and Pilar Zabala

2017 Survival and Abandonment of Indigenous HeadShaping Practices in Iberian America after European Contact. In Colonized Bodies, Worlds Transformed: Toward a Global Bioarchaeology of Contact and Colonialism, edited by Melissa Scott Murphy and Haagen D. Klaus, pp. 281-311. University Press of Florida, Gainesville.

Tilley, Lorna, and Marc Oxenham

2011 Survival against the Odds: Modeling the Social Implications of Care Provision to Seriously Disabled Individuals. International Journal of Paleopathology $1: 35-42$.

Tsukamoto, Kenichiro

2014 Multiple Identities on the Plazas: The Classic Maya Center of El Palmar, Mexico. In Mesoamerican Plazas: Arenas of Community and Power, edited by Kenichiro Tsukamoto and Takeshi Inomata, pp. 5067. University of Arizona Press, Tucson.

Tsukamoto, Kenichiro, and Octavio Q. Esparza Olguín

2015 Ajpach' Waal: The Hieroglyphic Stairway at the Guzmán Group of El Palmar, Campeche, Mexico. In Maya Archaeology, Vol. 3, edited by Charles Golden, Stephen Houston, and Joel Skidmore, pp. 30-55. Precolumbian Mesoweb Press, San Francisco.

Tsukamoto, Kenichiro, Javier López Camacho, Luz Evelia Campaña Valenzuela, Hirokazu Kotegawa, and Octavio Q. Esparza Olguín

2015 Political Interactions among Social Actors: Spatial Organization at the Classic Maya Polity of El Palmar, Campeche, Mexico. Latin American Antiquity 26:200 220.

Tsukamoto, Kenichiro, Fuyuki Tokanai, Toru Moriya, and Hiroo Nasu

2020 Building a High-Resolution Chronology at the Maya Archaeological Site of El Palmar, Mexico. Archaeometry 62:1235-1266. 
van Loveren, Cor

2013 Exposed Cervical Dentin and Dentin Hypersensitivity: Summary of the Discussion and Recommendations. Clinical Oral Investigations 17:73-76.

Voss, Barbara L.

2005 Sexual Subjects: Identity and Taxonomy in Archaeological Research. In The Archaeology of Plural and Changing Identities: Beyond Identification, edited by Eleanor Conlin Casella and Chris Fowler, pp. 55-78. Springer, New York.

Walker, Phillip L., Rhonda R. Bathurst, Rebecca Richman, Thor Gjerdrum, and Valerie A. Andrushko

2009 The Causes of Porotic Hyperostosis and Cribra Orbitalia: A Reappraisal of the Iron-Deficiency-Anemia Hypothesis. American Journal of Physical Anthropology 139:109-125.

Watson, James T., and Marijke Stoll

2013 Gendered Logistic Mobility among the Earliest Farmers in the Sonoran Desert. Latin American Antiquity 24:433-450.

Weiss-Krejci, Estrella

2011 The Role of Dead Bodies in Late Classic Maya Politics: Cross-Cultural Reflections on the Meaning of Tikal Altar 5. In Living with the Dead: Mortuary Ritual in Mesoamerica, edited by James L. Fitzsimmons and Izumi Shimada, pp. 17-52. University of Arizona Press, Tucson.

Weiss, Elizabeth, and R. Jurmain

2007 Osteoarthritis Revisited: A Contemporary Review of Aetiology. International Journal of Osteoarchaeology 17:437-450.

Wesseling, Janet, Sita M. A. Bierma-Zeinstra, Margreet Kloppenburg, Rik Meijer, and Johannes W. J. Bijlsma

2015 Worsening of Pain and Function over 5 Years in Individuals with "Early" OA Is Related to Structural Damage: Data from the Osteoarthritis Initiative and
CHECK (Cohort Hip \& Cohort Knee) Study. Annals of the Rheumatic Diseases 74:347-353.

Weston, Darlene A.

2012 Nonspecific Infection in Paleopathology: Interpreting Periosteal Reactions. In A Companion to Paleopathology, edited by Anne L. Grauer, pp. 491-512. Wiley-Blackwell, Chichester, UK.

Whelan, Mary K.

1991 Gender and Historical Archaeology: Eastern Dakota Patterns in the 19th Century. Historical Archaeology 25 (4):17-32.

Williams, Jocelyn S., and Christine D. White

2006 Dental Modification in the Postclassic Population from Lamanai, Belize. Ancient Mesoamerica 17:139 151.

Wright, Lori E.

1994 The Sacrifice of the Earth? Diet, Health, and Inequality in the Pasión Maya Lowlands. PhD dissertation, Department of Anthropology, University of Chicago, Chicago.

Zampetti, Stefania, Valentina Mariotti, Nico Radi, and Maria Giovanna Belcastro

2016 Variation of Skeletal Degenerative Joint Disease Features in an Identified Italian Modern Skeletal Collection. American Journal of Physical Anthropology 160:683-693.

Zuckerman, Molly K., Evan M. Garofalo, Bruno Frohlich, and Donald J. Ortner

2014 Anemia or Scurvy: A Pilot Study on Differential Diagnosis of Porous and Hyperostotic Lesions Using Differential Cranial Vault Thickness in Subadult Humans. International Journal of Paleopathology 5:27-33.

Submitted November 22, 2019; Revised May 19, 2020;

Accepted November 18, 2020 